\title{
Scholarship That Matters: Academic-Practitioner Engagement in Business and Management
}

\author{
TIM HUGHES \\ DAVID BENCE \\ LOUISE GRISONI \\ NICHOLAS O'REGAN \\ DAVID WORNHAM \\ University of the West of England
}

\begin{abstract}
Our research explores academic-practitioner engagement by undertaking interviews with academics, practitioners, and other experts with relevant engagement experience. The findings highlight the problem of thinking narrowly about the different ways in which engagement takes place, as well as defining narrowly what is a worthwhile activity for management academics. We develop a framework that encompasses the main ways in which engagement takes place, and that relates these to different attitude groups among both academics and practitioners. This could provide a starting point for business schools and individual academics to develop plans and put in place the processes for better engagement.
\end{abstract}

The relevance of academic research and teaching to practicing managers has been a subject of debate for many years, with the discussion becoming more intense in recent times (Bailey \& Ford, 1996; Bennis \& O'Toole, 2005; Leavitt, 1989; Mintzberg, 1996; Pfeffer \& Fong, 2002; Porter \& McKibben, 1988; Shapiro, Kirkman, \& Courtney, 2007; Starkey \& Madan, 2001; Van de Ven \& Johnson, 2006). Given the persistence of this debate and the importance of the issue to business schools, it is surprising that there has been little research into the actual ways in which knowledge passes between academics and practitioners in the management field. Starkey and Madan (2001) point out that there are no clear models relating to how management research is developed and disseminated between academics and practitioners. Baldridge, Floyd, and Markoczy (2004) argue that research is needed to better understand the relationship between academic quality and practical relevance.

The link to practice is important because it is about the question of how close academics are able to get to the reality of management in their research. If exchanges are limited to a small pro- portion of the academic and practitioner communities, how are academics in general meant to keep in touch with the reality of business practice? Even academics with practical experience are likely to lose touch pretty quickly from a lack of field exposure. Younger or less experienced academics may lack the experience to operate effectively at this level, but how are they to develop this experience and expertise?

Likewise, practitioners do not make the most of management academics as a source of knowledge. The significance of knowledge in relation to organizational survival (Kogut \& Zander, 1992) and competitive advantage (Lyles \& Salk, 1996; Zahra, Ireland, \& Hitt, 2000) has long been acknowledged. However, academics and their institutions compete with other knowledge sources and are only one of many potential knowledge partners (Van Wijk, Jansen, \& Lyles, 2008). In this respect, practitioners have to make choices as to the most suitable partners in different situations. It could be said that in a highly competitive world management academics do not "blow their own trumpet" loudly enough. 
The debate on academic-practitioner engagement within the academic community can be seen to take place on two levels. On the one hand, it raises fundamental issues of epistemology, relating to questions on the nature of scholarly work in the management field. This was touched on in the recent special section of $A M L E$ that focused on "Doing Work That Matters" (Bell, 2009), where the discussion related to how scholarly work in management is recognized and rewarded. On the other hand, the debate can also be seen to take place at a very practical level, relating to understanding the processes through which knowledge can most effectively be developed and exchanged.

We review the debate from these two perspectives and discuss the implications of findings from our research, which involved undertaking interviews with 68 respondents. They were chosen for their involvement in academic-practitioner engagement and were made up of academics, practitioners, and other experts with relevant experience in the management field. We will commence with a review of the debate concerning the academic-practitioner divide in management. In particular, this will be concerned with different perceptions over whether this is, in fact, a problem that management academics should be concerned about and the nature of the challenges involved. Based on literature from across the management disciplines, we argue that this is an important epistemological issue for academics working in the field, and we set out the aims of our research, leading into an outline of our methodology and to the research approach adopted. We then summarize our findings and open up a discussion on the possible practical implications for those in the management discipline who want to make their scholarship matter in the wider world.

\section{THE NATURE OF SCHOLARLY WORK IN BUSINESS AND MANAGEMENT}

The question of academic-practitioner engagement is a basic one in relation to how the discipline of management science has evolved over the past 30 years. Bennis and O'Toole's influential (2005) paper argues that business schools have adopted an inappropriate model of academic excellence in order to gain credibility within the university environment, measuring themselves solely by the rigor of their scientific research, thus becoming less relevant to practitioners. Broadly the argument is as follows: Because of the need to get academic status, business schools have become overfocused on analytics and problem finding rather than problem solving and implementation
(Leavitt, 1989; Porter \& McKibben, 1988). Management is taught as a science rather than as rooted in action (Bailey \& Ford, 1996), and this has led to a separation of management academics from the management profession (Pfeffer \& Fong, 2002). As a result, much of the teaching and research carried out in universities is irrelevant to the needs to business (Beer, 2001; Bennis \& O'Toole, 2005; Ghoshal, 2005; Mintzberg, 2004; Mintzberg \& Gosling, 2002).

A major concern, for some, is that business schools may lose their legitimacy in knowledge generation if their research is seen as irrelevant (Crowther \& Carter, 2002; Huff, 2000; Starkey, 2001). This could have potentially serious implications for future funding and the healthy operation of the sector. For those in the academic community who believe that those who apply academic knowledge are important stakeholders (Anderson, Herriot, \& Hodgkinson, 2001), the pervasiveness of the gap (Rynes, 2007) can be a source of some despair.

However, there is a counterargument that warns business and management academics of the dangers of moving too far to close the gap. Its essence is that academic freedom is best served through a degree of separation. If business schools are no more than producers of commercially usable knowledge, they stand to lose what makes them distinctive (Grey, 2001). Business schools do not exist just to serve the profession of management (Starkey \& Tempest, 2008), and much knowledge emerges from fundamental research that is not known to be useful at the time of doing the research (Weick, 2001). There is also the question of power. Learmouth (2008), sees a threat to academic pluralism from practice-based approaches that legitimize a particular elite view of the world. While less has been published from those defending an "arms-length" approach to practice, the acknowledgement of their concerns is important. We are reminded that management research is a fragmented field in which there is little paradigm consensus (Tranfield \& Starkey, 1998).

A useful contribution to this discussion is the distinction made between explanatory sciences and design sciences (Von Aken, 2004). The explanatory paradigm, as predominantly followed in business schools, is concerned with understanding what is, while design science (as predominates in medicine and engineering) is concerned with what should be. Design science is concerned with developing knowledge that provides answers to problems. Van Aken (2004) argues that successful scholarship requires a partnership between the explanatory sciences (where the output is a causal model developed in controlled conditions) and the 
design sciences (where the output is technological rules developed in context). Achieving such a balance of scholarly quality and managerial relevance (Pettigrew, 1997) implies a reorientation of the management field toward design science that would emphasize work that is prescriptive, field tested, and grounded in practice (Huff, Tranfield, \& Van Aken, 2006). Furthermore, the prescriptive approach can also be seen to involve a moral dimension, addressing Ghoshal's (2005) critique of business schools, by making it incumbent on academics to also focus on the impact of business activities on the community (Huff \& Huff, 2001).

\section{THE SOCIAL PROCESS OF ACADEMIC-PRACTITIONER ENGAGEMENT}

At the heart of our argument is the view of knowledge creation as a social process (Amabile et al., 2001; Nonaka, 1994; Tsoukas, 2005). A strong theme in contemporary organizational thinking is to recognize that knowledge is socially constructed in communities and is not confined to formal sources of information or data (Lang, 2001). Knowledge cannot be seen solely as disembodied, formal, and divorced from context (Blackler, 1995; Cook \& Brown, 1999; Lave, 1993). Knowledge creation involves learning through participation and interaction (Amabile et al., 2001; Nonaka, 1994; Tsoukas, 2005), and has been portrayed as a spiraling process of interactions between explicit and tacit knowledge (Nonaka, 1994).

The body of literature on knowledge management emphasizes the perspective of organizations as social communities specializing in the creation and transfer of knowledge (Kogut \& Zander, 1992). An organization's knowledge base is seen to be a major source of competitive advantage. However, sharing knowledge between communities can be challenging (Brown \& Duguid, 1998), particularly where the knowledge to be shared is complex (Hansen, 1999). An understanding of how to create the conditions for effective exchanges of knowledge requires consideration of the soft factors in communication between communities, such as the degree of mutual understanding between receiver and sender, and their underlying assumptions and motivations (Guzman \& Wilson, 2005). It is necessary to encourage individuals to interact, codify, and share their knowledge internally to build the firm's knowledge base, as well as to interact with external communities to access outside knowledge (Birkinshaw, 2001).

The importance of social processes in knowledge creation is pertinent to the way the problem of academic-practitioner engagement is ap- proached. Where the gap is framed in terms of being about knowledge possession, the failure is understood to be about ineffective transfer of academic knowledge (Tranfield, Denyer, \& Smart, 2003). However, Van de Ven and Johnson (2006) argue that it can be a knowledge-production problem, requiring a two-way coproduction of knowledge between academic and practitioner communities. Shapiro et al.'s (2007) research with Academy of Management (AoM) members found that they support the argument for both ways of framing the problem. That is to say, while poor communication to practitioners is an issue, the involvement of practitioners in creating knowledge is equally important. This conclusion supports Tranfield and Starkey's (1998) argument for the inclusion of mode 2 approaches in producing management knowledge.

The generally poor level of engagement between academics and practitioners, highlighted in the literature, is therefore of concern because social interaction is so fundamental to knowledge creation. The absence of sufficient direct interaction between these communities means that there is a lack of the dialogue and debate that is essential for the effective development of the discipline. Rynes' (2007) message is pertinent here. Academics should seek interaction with practitioners despite the possible tensions involved, because interaction is so fundamental to knowledge creation.

\section{THE NEED FOR A BETTER UNDERSTANDING OF ENGAGEMENT}

Criticisms regarding the quality of engagement between academia and practice are not restricted to the organization sciences. Gibbons et al.'s (1994) influential ideas on mode 2 knowledge production apply to the whole landscape of science and technology. In mode 2, the social context of knowledge production is crucial. In contrast to the mode 1 science push model, mode 2 is based on an interaction model, emphasizing the relationship between researchers and users at different stages of knowledge production, dissemination, and utilization (Nowotny, Scott, \& Gibbons, 2001). It is very difficult to make meaningful comparisons between business and management and other disciplines, and therefore, we would not claim that business and management is either better or worse than other fields of study in relation to engagement. What seems to be important is that one of the key defining characteristics of business and management research is its applied nature (Tranfield \& Starkey, 1998). It therefore fits well into a mode 2 approach. 
There has been a certain amount written about the need to involve the proctice community in designing and undertaking management research. Shrivastava and Mitroff (1984) argued that by consciously formulating research questions in terms of managerially controllable variables, researchers would be more likely to obtain results that prompt actions. In doing this, cooperation with companies becomes a prerequisite for the production of actionable knowledge rather than an outcome (Hatchuel, 2001). Some empirical evidence suggests that practitioner-academic partnerships can lead to better management research and its greater utilization by practitioners (Amabile et al., 2001; Landry, Amara, \& Lamari, 2001). Suggestions for achieving this include the setting up of partnership teams (Cyert \& Goodman, 1997); practitioner participation in interpreting research (Amabile et al., 2001; Mohrman, Gibson, \& Mohrman, 2001); and the involvement of practitioners in problem formulation, theory building, research design, and problem solving (Van de Ven \& Johnson, 2006).

There is also on established model that considers the triangular relationship between teaching, research, and practice, with two-way relationships between each of the three elements (Kaplan, 1989). Burke and Rau (2010) have recently argued that better integration of teaching and research would be beneficial to narrowing the academic-practitioner gap.

However, there remains the fundamental question, as articulated by Shapiro et al. (2007: 262): "Is creating a more continuous two-way dialogue between researchers and practitioners doable?" While there has been much research in recent years in the general field of interorganizational knowledge transfer (Van Wijk et al., 2008), there is a knowledge gap relating to understanding the process of development and exchange of knowledge between academics and practitioners and their organizations (Rynes, 2007; Shapiro et al., 2007; Starkey \& Madan, 2001). For those management academics that agree with Adler and Harzing's (2009: 91) view that "academia needs to shift to designing and implementing environments that purposefully encourage research that matters," what needs to be done to improve the processes through which academic-practitioner engagement takes place?

The research reported here starts to explore engagement by interviewing academics and practitioners who do engage with each other. We review the evidence on the social practice of engagement and consider the various routes through which engagement takes place in relation to knowledge transfer and knowledge exchange. This leads to a discussion designed to add to the current debate on how to create conditions likely to improve engagement.

\section{METHODOLOGY}

The specific objective of the research reported here is to better understand academic-practitioner engagement. The following research questions and subquestions provided the starting point for our research:

1. What are the practices and processes associated with knowledge development and exchange between academics and practitioners?

- How is knowledge exchanged?

- How effective and efficient are the different methods of exchange?

- What are the triggers and barriers to knowledge exchange?

- What characterizes good and bad practice?

2. What are the characteristics and behaviors of academics and practitioners who engage with each other?

- What are the attitudes of those involved in engagement activities?

- How do they view the use of theory in the practice of business and management?

- How do practitioners view academics and viceversa?

- How do they think their colleagues view this type of engagement?

The interviews were semistructured, based around a framework designed to ensure that they covered common areas. The starting point for each interview was to get the interviewees to start talking about their experiences of academic-practitioner engagement. In doing this, we aimed to allow the interviewees to go into as much depth as they wanted in their areas of particular interest. An interview guide was used by the interviewer to ensure coverage of aspects not spontaneously mentioned by the interviewee. The interviews were all conducted by the authors of this paper, with each author interviewing those within their own field of expertise.

In managing a diverse team of researchers, it is crucial to put in place sufficient research protocols and processes to ensure dependability and confirmability of the findings (Lincoln \& Guba, 1985). The first named author provided continuity across all subprojects. There was careful control of the way the data was collected, coded, sorted, and analyzed (Miles \& Huberman, 1994). All interviews were recorded and transcribed. The NVIVO software package was used to facilitate the analysis, and this proved valuable in handling a large 
amount of data. The first named author of the paper conducted all coding in close liaison with the academics who had conducted the interviews. Through controlling the coding and analysis process in this way, it was possible to compare and contrast responses concerning common issues across the range of interviews.

In undertaking this research we took a critical realist approach. The critical realist perspective allows for pluralism of perspectives in looking at complex phenomena, where different views exist (Van de Ven, 2007). It is well established as one of the major research paradigms (Guba \& Lincoln, 1994), taking the point of view that there is a real world to discover, but it is only ever imperfectly understandable (Godfrey \& Hill, 1995; Tsoukas, 1989). Critical realism allows for the independent existence of the social world made up of abstract ideas (Magee, 1985). Within this paradigm, indepth interviewing, as used in our study, is considered to be a very suitable method for probing into a complex social phenomenon (Healy \& Perry, 2000). Furthermore, qualitative approaches investigating perceptions are recognized to have value in understanding the complex area of knowledge and learning (Sammarra \& Biggiero, 2008).

The research covered here comes from interviews conducted by the authors in the United Kingdom across the marketing, accountancy, strategic management, and organization studies disciplines. Business and management contains a number of different fields, and there is no universally agreed definition of the disciplines that should be included in this area. However, the four disciplines focused on here reflect core subjects offered in most business schools, and most importantly, reflect the range of expertise represented by the authors. In conducting interviews across a number of disciplines, we considered it essential to have expert interviewers who research and teach within each discipline chosen. The cross-disciplinary makeup of the team had many advantages in widening the research rather than constraining it within one discipline. The four disciplines chosen represent a range of relationships with practice. Accountancy is highly professionalized, with the professional bodies controlling the license to practice. Marketing and strategic management are less controlled. Professional bodies exist, but practice is not confined to members of these professional bodies. Organization studies is at the other end of the continuum from accountancy, with its emphasis on the study of organizations, rather than the professionalization of practice.

A purposive sampling approach was taken, through selection of interviewees relevant to the processes being studied (Denzin \& Lincoln, 2002; Mason, 1996) that were well situated to illuminate the issues (Gerson \& Horowitz, 2002). Thus, our aim was not to provide a sample that represented all academics or all practitioners. Our respondents were individuals who were approached because of their involvement in some form of academicpractitioner engagement. The interviewees were contacted through the extensive network of contacts of the authors of this study. The network was then extended by "snowballing" from the initial respondents, in order to identify others who were suitable (Mason, 1996; Patton, 1987). The interviews that took place, within each discipline, broke down as seen in Table 1.

The Appendix provides brief descriptions of the role and responsibility of each interviewee, demonstrating their suitability and credibility for involvement. Selecting interviewees on the basis of their credibility and expertise in the area of research is a well-established practice (Marshall \& Rossman, 1989), that puts an emphasis on the validity of the research through getting close access to the phenomenon under study (Gummeson, 2002). The other aspect of the sampling approach was to gain perspectives from different stakeholders in the management field. Hence we interviewed academics (20 interviews), practitioners (28 interviews), and consultants/experts (20 interviews). The consultants/experts group consisted of commercial consultants, senior staff from professional bodies, and expert commentators not directly falling into either the academic or practitioner groups. The consultants/experts group was included because its members could give third-party perspectives from a position outside of either academia or practice. The interviews were either conducted face to face (40 of 68) or over the telephone (28 of 68).

As a research team, we took the approach of analyzing the data throughout the research program in an iterative process, building our understanding progressively from the interview data, as it became available. Following in the spirit of this

\section{TABLE 1}

Interviewees by Discipline

\begin{tabular}{lcccc}
\hline \multicolumn{1}{c}{ Discipline } & Academics & Practitioners & Experts & Total \\
\hline Marketing & 7 & 7 & 7 & 21 \\
$\begin{array}{l}\text { Accountancy } \\
\text { Strategic } \\
\quad \text { management }\end{array}$ & 4 & 6 & 4 & 14 \\
$\begin{array}{c}\text { Organization } \\
\text { studies }\end{array}$ & 6 & 9 & 5 & 17 \\
Total & 20 & 6 & 4 & 16 \\
\hline
\end{tabular}


approach, our discussion of the findings below also contains a significant amount of analysis as it progresses. The authors believe that the project benefited by following this iterative process, and assessing the significance of what was said by the research participants as the research evolved. The authors' collective experience of the politics of practice and academia was found to be invaluable in this.

\section{THE PRACTICES ASSOCIATED WITH EFFECTIVE ENGAGEMENT}

As a starting point, we will summarize the different ways in which, according to our interviewees, engagement occurred. We call these "routes to engagement" and illustrate them in Figure 1.

Most of the routes through which engagement can take place are self-explanatory. One route that perhaps does require a little explanation is that of "knowledge networks." We found a number of examples of formal and informal networks that had been set up expressly to provide a means for engagement. One of the most successful has been running for over 13 years, providing an industry forum within a particular sector. It involves major organizations from the sector, academics working in the area, and policy makers and regulators. One participant, "Acmar3," puts its continuing success down to very active management and a willingness to evolve in order to provide continuing value to its members:
I am just about to start a program of spending three or four months visiting all of our members ... I act as the primary catalyst for change, but we do make it our business to get a lot of feedback from our supporters. Acmar3

The network mentioned is quite formal, involving a significant level of funding from its members. Other examples from our research were less formally structured. "Acmarl" has been running his own knowledge network for many years, relating to information technology and customer management, providing a range of opportunities for academics to present ideas, and gain up-to-date insight into the challenges faced by practitioners. Like the previous example, Acmarl makes the point that running a successful network takes considerable effort and the skills to liaise with a number of different parties.

Figure 1 also features two major intermediaries (commercial consultants and professional bodies), identified in our research. These intermediaries can be seen to act in conjunction with the main routes to engagement, to a greater or lesser extent, within different management disciplines. For example, within the accountancy discipline, where the professional bodies are particularly powerful, they often play a "bridging role," setting relevant agendas for teaching and research:

It needs an intermediary and I think we can do that because, you know, we are talking to

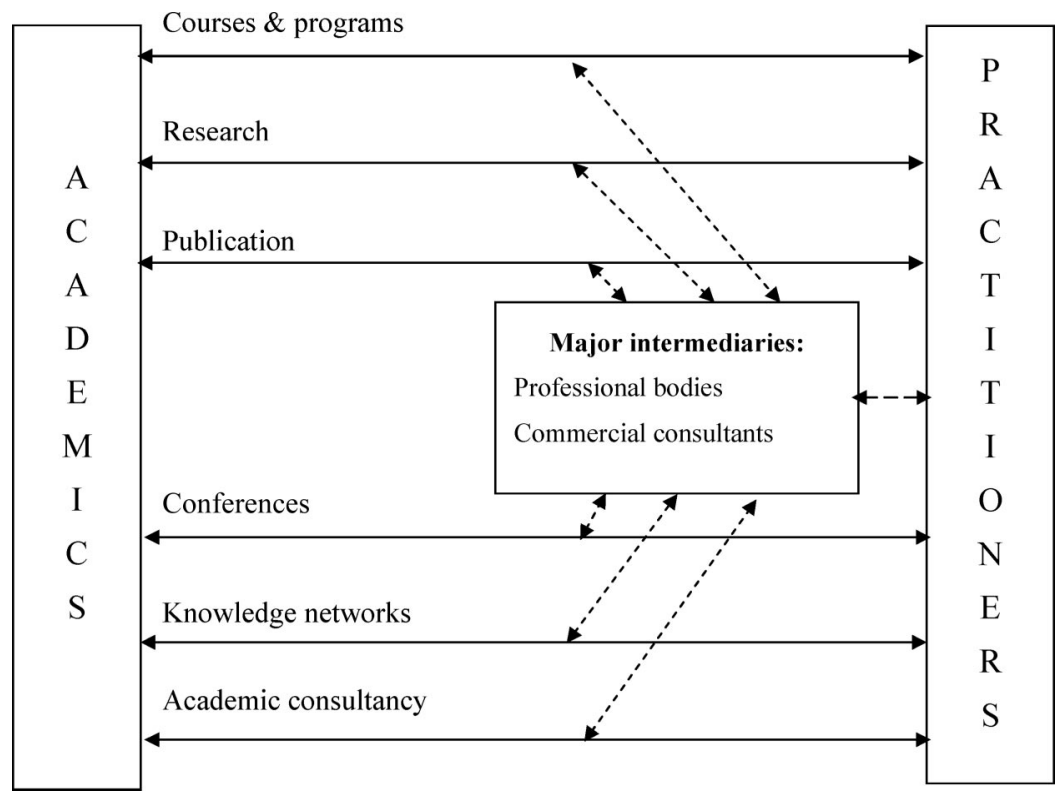

FIGURE 1

Routes of Academic-Practitioner Engagement 
the academics and we're sort of thinking about issues like Measurement, like Reporting Models for Business, where we know that practitioners are interested, we know that there are also academics who are doing relevant work and so we can bring the two sides together. Conacc8

Professional bodies often play an important role in commissioning research, allocating funds for research by academics, and in setting up joint research committees where academics and practitioners can work together. From an academic's point of view, as well as funding for research, a professional body can provide a number of opportunities for practical research.

The other major intermediary route to engagement is commercial consultancy. "Conmar2" considers his training consultancy's link with a leading UK business school to have been very important in setting the business up, enabling the consultancy to keep abreast of academic developments. An academic from the business school supplies the body of knowledge, and the consultancy concentrates on its application. Equally, the training consultancy, in interacting with its clients, sometimes picks up on the development of new problems and issues before the academic community. Other consultants that we interviewed also acknowledged the benefit of having access to the latest academic research, in one case through taking an $\mathrm{MBA}$, and in another case through taking a DBA. In these cases the consultants concerned are playing an important translation role, that of making relevant academic theory usable in the context of their clients' particular problems.

It is when we consider the ways in which each route can be said to effectively enable knowledge transfer or exchange, that the results become most interesting in considering the practice of engagement. Providing evidence that learning has actually occurred through engagement is problematical (Easterby-Smith, Lyles, \& Tsang, 2008), and this is where the in-depth probing that is possible in qualitative research is particularly valuable in developing understanding. In analyzing the interviews we have adopted the distinction between transfer (relating to one-way communication of knowledge) and exchange (relating to two-way knowledge creation), as used by Van de Ven and Johnson (2006) and Shapiro et al. (2007). Table 2 summarizes our findings in this regard.

\section{The "Courses and Programs" Route}

At the undergraduate level, the recruitment of recent graduates can be seen as an important source of bringing up-to-date theory into practitioner organizations, as illustrated by this quote from $a$ partner in an accountancy firm:

I think you will see it coming in through the bottom. ... partners tend to be dinosaurs and our job is to understand the commercial drivers of our clients, not necessarily the latest theory or the finest points of financial report-

TABLLE 2

Effectiveness of Routes for Engagement in Enabling Knowledge Transfer and Knowledge Exchange

\begin{tabular}{|c|c|c|}
\hline Routes to Engagement & Knowledge Transfer & Knowledge Exchange \\
\hline Courses \& programs & $\begin{array}{l}\text { - Great variability in application into practice } \\
\text { - Indirect through undergraduates } \\
\text { - More direct through postgrads and executive courses }\end{array}$ & $\begin{array}{l}\text { - Can be a "touch point" with practice, } \\
\text { but not a systematic source of } \\
\text { knowledge }\end{array}$ \\
\hline Research & $\begin{array}{l}\text { - Certain research approaches such as action research } \\
\text { can be effective, but this is not the case with the } \\
\text { majority of types of research }\end{array}$ & \\
\hline Conferences & $\begin{array}{l}\text { - Limited number of conference forums that cross over } \\
\text { between the two communities }\end{array}$ & \\
\hline Knowledge networks & $\begin{array}{l}\text { - Where active can be effective way to disseminate } \\
\text { relevant theory and models to interested parties }\end{array}$ & $\begin{array}{l}\text { - Where active can provide a forum for } \\
\text { dialogue and a source of support for } \\
\text { relevant research }\end{array}$ \\
\hline
\end{tabular}


ing. That actually comes in from the machine behind us. ... it sort of feeds in at the more junior levels and goes up into the firm that way. Praccll

At the postgraduate level the knowledge transfer link will tend to be more direct. Prmarl found that a part-time MBA provided him with models that helped him simplify real business problems and solve them. Many of these were simple models that people within his organization (one of the largest global blue-chips) were not aware of. For Conmar3, a recently completed MBA served to remind him of the basics and refresh his thinking. However, embedding the learning from courses and programs in organizational practice is often not that effective:

It needed the organization to actually understand that knowledge was critical to its future, and it needed the university to understand that working together with the business was critical to its future, and it didn't quite work that out. Conmar5

The knowledge transmitted through "courses and programs" is often theoretical, and across a wide range of contexts; therefore, it needs to be selectively and appropriately adapted to the organizational context.

\section{The "Research" Route}

Research, in itself, can be a route to engagement, where it involves the researcher as an agent of change rather than purely an observer, as is the case with participative types of research, such as action research. Participative and collaborative research is particularly encouraged in some management disciplines. Where this is the case, this type of research has the potential to offer both knowledge transfer and exchange, covering knowledge that is applied and context specific. However, there are many fields of management where participative and collaborative research is discouraged by lack of inclusion in top-ranked journals and, in turn, by audits of research quality.

\section{The "Publication" Route}

Across the management fields we studied, one of the most consistent findings was that practitioners seldom read academic journals and when they do, they are put off by the language, content, and style:
Academics tend to write for themselves in arcane journals, and even if an MD is given one, he/she would not want to read past the first page. The articles are often shown to demonstrate what the academic knows rather than what is useful to someone doing the job. Constrat16

Few small business managers read academic journals.... (they are) too busy to bother with what they see as high-level theory, and are more content to attend trade conferences and exchange information between themselves. Constrat18

A summary of the views expressed in the interviews is that academic journals are inaccessible to practitioners because of their language, style, and poor readability, and there is a need for translation to distill the information into a meaningful and relevant framework. While popular business publications disseminate information much more widely, they have a limited role in disseminating academic research, often are seen as the domain of journalists, and as containing few articles from academics. We did speak to editors concerned with hybrid journals that specifically try to appeal to both practitioner and academic audiences, but in these cases the practitioner component had proved difficult to sustain. There are exceptions, such as the Harvard Business Review and some publications from the larger consultancies. However, a fair summary of our respondents' views is that there are few common publication arenas where academics and practitioners debate or share knowledge. The point here is that potentially useful research knowledge is not effectively transmitted. There is, perhaps, a need for the development of more academic management writers, who can effectively engage with, and excite the interest of, the broader business and management population.

\section{The "Conference" Route}

This problem of lack of common areas where academics and practitioners might maintain a dialogue was also evident in the interviewees' comments on conferences. While we did find examples of conferences set up by academics for both communities, it can be difficult to attract large numbers of practitioners. In particular, the input from academic speakers needs to be credible and relevant if attendees are to feel that they have gained value: 
You have to know that what you are providing is something they will find of value, and if you haven't done your homework you really aren't up to speed with what is going on in professional practice, they will crucify you. Acmor4

Conferences do have the potential to facilitate both knowledge transfer and knowledge exchange, but in reality there are few that truly attract both parties. Achieving the presence of both parties at conferences is problematic. It is crucial that the subject matter is of mutual interest, raising the issue of how much common ground the two parties actually share.

\section{The "Knowledge Networks" Route}

Formal or informal knowledge networks exist in order to share information between members. In the accountancy field, where there are strong professional bodies, we found little evidence of networks involving both academics and practitioners outside of those provided by the professional bodies. In contrast, in the marketing field, where the professional bodies are weaker and less formal, networks can play an important role in academicpractitioner engagement. These networks would seem to provide great potential for social interaction between the academic and practitioner communities, and hence, may be very important for cocreation of knowledge. This route focuses on knowledge that is applied and pragmatic, often in very specific contexts. However, successful and long-term networks are said by our respondents to be few and far between.

\section{The "Consultancy" Route}

At their best, academic consultants were seen as capable of making a very real contribution to practice, through widening the intellectual resource available to the client, bringing an objective expertise, and acting as a knowledgeable facilitator. In order to get in this position, the individual academic needs to have the track record and ability to undertake direct consultancy. For this reason academics invited into the company or organization will tend to have significant industry knowledge rather than simply theoretical knowledge. The academic's ability to apply theory requires an understanding of the company or industry context. However, the idea of the academics as "experts" runs the risk of putting them on a pedestal, and treating them in an unquestioning manner, as a kind of guru. Acmarl, an academic who has had a long and successful consultancy practice, stressed the importance of engaging with proctitioners on an equal footing. He believes academics should take port in:

frequent in depth consulting, in which you are looking at the issues and arguing the toss, and not behaving like a guru, but as a peer amongst senior people where you are open to be questioned. Acmarl

Conducted in this way, consultancy carries the potential for knowledge exchange and sometimes provides opportunities for joint publication and conference presentations with practitioners. The nature of the knowledge exchanged tends to be applied and pragmatic and related to a specific context. However, the consultancy route posed the most ethical dilemmas for academics in relation to their own independence and the motives of the client for using them. Furthermore, commercial confidentiality may pose restrictions on wider dissemination of knowledge gained through this route.

\section{THE PEOPLE INVOLVED IN ENGAGEMENT}

Within the academic community, individual attitudes toward working with practice seemed to reflect the lack of consensus revealed in the literature. However, in analyzing our interviews we discerned three distinct attitude groups that might be worth further investigation. First, we found many academics that engage with practice as a matter of course and believe that it is fundamental and greatly enriching to their scholarship:

I think the thing that gives me the greatest satisfaction as a researcher is when people actually use the research I have generated; or you go to a practitioner conference, and there are two or three speakers referring to research that I have done; or they are using the model that I taught in the past. Because you know you are making a practical difference. Acmar4

There is a kind of, a sense of an underlying value which revisits from time to time, and one is unconscious of. It relates to beneficial change, social benefit, making a difference, making a positive difference. Acorgl6

We would characterize these as the "Willing \& able" group of academics, who currently do work with practice, having both the experience and 
the motivation. At the same time, many of our interviewees mentioned individual academics that do not wish to engage with practice, some of whom believe that this should not be part of their role. We would characterize this group as the "Theoreticians," who have no wish to engage with practice:

If I look around ... I mean I think there is unwillingness, a simple unwillingness, (among) many of my colleagues to want to communicate to the sorts of issues and problems that many practitioners really face, sadly, you know. Acorgl3

I think there are a few people, quite a minority, who would look with disdain on the world of practice. I won't name names, but there are one or two ... but they look askance at people in practice in principle, because they think it's contaminated, caught up with capitalist values and they are out really to provide critique of that whole system, so they look askance at any kind of involvement of practice. Acorgl 4

Alongside these polarized views, our research suggests that there is also a third group of management academics, who are not strongly negatively disposed to working with practitioners, but only have limited opportunities to do so. We classify these as the "Willing, but underexposed" of those who would like to engage more, but lack the experience. In this respect, the credibility of individual academics in engaging with practice emerges as an issue:

I think that there's a credibility issue ... The credibility of the academics for the practitioners. You know the practitioners see the academics as removed from it; from the action as it were. Acacc8

Another barrier is to do with source credibility: beyond Harvard and a few others academics have little credibility in the business community ... Too often delivery is by people without exposure to industry. Acstrat19

I think part of that lies in the fact that although many academics in marketing, for example, are fully engaged with industry, they're interested and so on, they perhaps lack the confidence, or indeed the connections, or practical experience to actually criticize. Acmarl
And the other thing we have learnt is that the academic community has difficulty in very practical terms in presenting its work to the practitioner community. Acmar3

This raises the question of how younger management academics learn to deal with the practitioner community:

The general culture in most universities as I see it is you eat what you kill and you go out and make your own way, and it's a very individualistic culture. There's no sense of the collective, you sink or swim as a young researcher. Acmor5

Following from our research we would suggest that it might be useful to consider academics within the management field in terms of these three segments in relation to engagement: The "Willing \& able"; the "Theoreticians"; and the "Willing, but underexposed."

On the practitioner side, in terms of attitude and motivation we also found distinct groups. We have called these the "Enthusiasts," the "Uncommitted," and the "Cynical." Because of the nature of our sample, many of the practitioners that we interviewed had embraced academia and been proactive in developing links. We would characterize these as "Enthusiasts" in relation to engagement. For example Prmarl had been involved in a number of academic-practitioner networks in his senior management role, within a multinational blue chip company. Prmarl related how education had been a continuous process for him as he developed in his career:

I think we are unusual people in the way we work, and other people rely on us to be information brokers. I am not quite sure how this has come about, but it does go back a long way ... But I wanted to keep learning, so I did HNC computer studies and BCS exams and I've never stopped. So then I did a Diploma in Accounting \& Finance and, of course, the MBA, and I did the marketing .... I've never stopped.... So it's a continual selfdevelopment program. There are people like this, I know other people like this, but they are not the norm.

As Prmarl notes, his experience is not typical and for the great majority of practitioners the immediate demands of their role seem to take priority over ongoing development. For this reason, we suggest that there is a group of practitioners who we call 
the "Uncommitted," who may be open and sympathetic to academic work, but do not maintain these links on an ongoing basis because of other priorities:

I find it quite challenging just to get through the necessary technical reading. There's only so many hours in a day. I get to work, I don't know seven thirty in the morning, leave seven o'clock at night. Sometimes work much later. And somehow within that working day, and there's not really a slot for it, I have to update myself with all the technical material. Pracc8

What you get there is a lot of people who's ... and this happens all the time in corporates, their nose is down at the grindstone and churning out charts for management meetings, and they never get any downtime, they never get to step back and think about where this is going. Acmar5

On the other hand you have got industry, which over the last 10 or so years has become ever more focused on bottom line short-term profit. And so, the pace within industry keeps quickening up and, in part, technology has driven that. People's days are being driven by emails for example and the technology, in my judgment, for from making business more efficient and effective, is in many ways making it less efficient. Because there is less proactive management of executive time and more reactive usage of executive time. So this adds to an overall culture in which short-term activity, fire fighting, becomes ever more the norm. Acmar3

As a result of these pressures practitioners often seem to require simplistic answers to complex problems:

From the practitioners view they want silver bullets as they avoid complexity. When the two sides are not even talking on the same plane, then communication is impossible. Constrat 16

I sympathize with the emotion that lots of practitioners feel, that they want a list, they want it to be simplified, but it cannot be so. Acorgl7

As suggested by this last quote, simplification may not be possible and desirable, and therefore, the academic needs to find more practitioners like Prorg 15, who are prepared to be open in their thinking:
Exactly right, exactly right! It's challenging my thinking. That to me is the key thing for me, going out talking to you guys, because I can go in this direction and no one will challenge me in the organization apart from "we can't afford to do it." Prorgl5

Targeting those who are attitudinally likely to respond positively is crucial:

I would say possibly $20-30 \%$ of the people really got fired up about new ideas and they are basically just creative tools to enable them to think in a different way. They got really fired up about it. The rest actually thought it was a waste of time, a waste of their time, because they had to be focusing on their business plans, which is quite interesting, isn't it? I suppose that's what I mean by you have to pick your people to sometimes apply more theoretical concepts. Conmar5

Three segments of practitioners are suggested by our research: the "Enthusiasts" as epitomized by Prmarl above, who actively embrace links with academia; the "Uncommitted," made up of those who may be open and sympathetic to academic work, but do not maintain these links on an ongoing basis; and finally a group who may be closed to academia and academic ideas. We call these the "Cynical."

As exemplified by our research, there are many academics engaging with practice and a number of practitioners who are open to engagement. The problem is not that academics and practitioners do not engage with each other. The problem is the narrowness of the engagement, being generally limited to those we term as the "Willing \& able" academics and the "Enthusiast" practitioners. As illustrated in Figure 2, the challenge is about depth of engagement on both sides.

The solid arrow represents the existing relationship between the "Willing \& able" group of academics and the "Enthusiast" group of practitioners. The arrows with the dotted lines illustrate the areas for potential development, with the "Uncommitted" group of practitioners and the "Willing but underexposed" group of academics. The "Enthusiasts" seem to be open to academic ideas and prepared to pick and choose between models and ideas, selectively applying those that they identify to be relevant. This group would seem to be more open to routes to exchange, such as courses and programs, that offer exposure to theories and more general concepts. In contrast the "Uncommitted" and "Cynical" groups would seem to be more 
closed to theory, where it is not seen to be relevant to their immediate context and particular challenges. The "Uncommitted" group in porticular might be more likely to respond to engagement routes that emphasize pragmatic knowledge development related to specific contexts, such as a knowledge network or a consultancy program.

\section{ENGAGING APPROPRIATELY: THE RIGHT PEOPLE AND THE RIGHT ROUTES}

Our review of the effectiveness of knowledge transfer and knowledge exchange, across the different routes, touches on many of the reasons for the lack of effective academic-practitioner engagement. As depicted in Table 2, every route has its own limitations, and therefore, we conclude that engagement needs to take place across multiple routes in order to be effective in relation to different proctitioner segments. This includes routes outside of traditional teaching and research, which provide greater opportunities for social and informal interaction. In our research, we found a number of successful knowledge networks, where a common feature was that academics had taken the lead in working with a range of practitioners and policy makers, in developing common agendas for future research. A network can also provide a means to access research subjects among network members and a forum for disseminating and discussing the implications of the research results. In this, the academic con overcome the limitations of the inaccessibility of traditional publications to the practitioner community by translating, synthesizing, and interpreting the results. At the same time, we would not want to paint too rosy a picture. Other research has pointed to the complexities and uncertainties of such collaborations (Alteroff \& Knights, 2009), and our research found that they tend to break up easily. Therefore we should not underestimate the skills and resources required to maintain successful engagement.

Achieving impact outside of the academic community generally requires participation in routes that inevitably involve close interaction, as well as the building of relationships between academics and current practitioners. This requires a design science approach (Van Aken, 2004, 2005) in so far as the practitioners involved will be interested mainly in knowledge that is valid to field problems. The practitioner view on the appropriateness and applicability of the content of academic management research needs to be taken into account. Others (e.g., Bailey \& Ford, 1996; Guest, 2007) have stressed the importance of the relevance of subject matter to practitioners' immediate needs. Mode 2 (Gibbons et al., 1994) approaches to knowledge generation recognize that knowledge development takes place iteratively, with a series of interactive exchanges between the parties involved. Our research points to ways in which effective engagement can be established, for a much more balanced and two-way interaction that provides demonstrable value to both sides.

At the same time, our research suggests that if engagement is to be effective, it is also crucial to identify the right people on both sides, as illustrated in Figure 2. Therefore, we argue that it is important to distinguish between academics that might feel compromised by engagement (Grey, 2001; Learmouth; 2008), whom we have called the "Theorists," and those that have had little opportunity to engage, the group we have called the "Willing but underexposed." Arguably, it is this group where the most effort needs to be made, in order to support them in working with practice. It is this latter group that would benefit most from

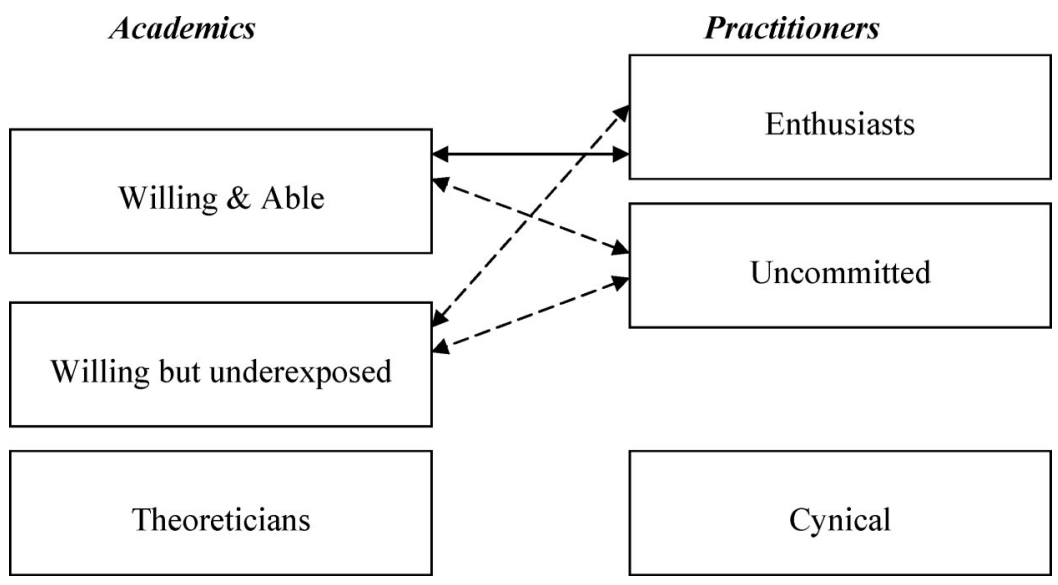

FIGURE 2

Engagement by Attitude Group 
training, support, and mentoring. On the practitioner side, the focus should be on the "Enthusiast" and "Uncommitted" groups.

We therefore propose that a useful framework for considering academic-practitioner engagement is to focus on the two key elements of (1) the right people (by attitude), and (2) the routes through which they engage, as illustrated in Figure 3.

We believe that the strongest engagements take place where "Willing \& able" academics engage with "Enthusiasts" across a large number of different routes. Greater depth of engagement between the communities will be achieved where "Willing \& able" academics are able to engage more "Uncommitted" practitioners, through more use of unconventional routes such as knowledge networks. But, most important for the future, the "Willing but underexposed" group of academics needs carefully controlled involvement across a wide range of routes if we are to develop a bigger group of "Willing \& able" academics.

\section{CONCLUSIONS AND IMPLICATIONS}

As established at the commencement of this article, there is widespread concern among academics across business and management disciplines about the academic-practitioner gap. Much has been written about the problem, but little about the lessons to be learned where engagement is taking place. The contribution of our research is to put forward a framework that encompasses the main ways in which engagement takes place and relates these to different attitude groups among both academics and practitioners. As with all qualitative research, we must acknowledge its limitations in terms of generalizability. Our purposive sample of 68 interviewees, all undertaken in the United Kingdom, produced a wealth of valid and interesting data. However, the reader must judge the applicability of these findings in different contexts and cultures.

Through analyzing the routes by which academics and practitioners may transfer and exchange knowledge with each other (see Tab. 2), the poten- tial limitations of overdependence on any single route are exposed. This highlights the problem of thinking norrowly about the different ways in which engagement can take place, and defining narrowly what is a worthwhile activity for management academics. From a practical point of view, the map of routes to engagement (see Fig. 1) could provide a starting point for business schools to develop strategic plans and put in place the processes for better engagement. Our research suggests that business schools need strategies that address multiple routes and recognize the varying needs of different attitudinal groups among practitioners. Nontraditional routes, such as knowledge networks and consultancy, may well be necessary to reach new groups of practitioners, such as the "Uncommitted" and the "Cynical."

The development of relationships with practitioners does not happen automatically. This raises the point about ways in which business schools and their academic staff can be most effective in reaching out to the various communities that they serve. While we found some individual academics that had intricate webs of practitioner and policymaker relationships, there would seem to be the potential for business schools to be more proactive in broadening and deepening the links and involving many more academic staff in this. To do so will require significant investment of time and resources on the part of individuals and institutions. Again, the will to make this investment will depend on individual and institutional motivation, in relation to the perceived importance of crossing the academic-practitioner divide. Our research suggests it is not as simple as putting effort into reaching out into the practitioner community, in an attempt to create relationships and communities. We found many examples where considerable effort had been put into these types of initiatives with disappointing results. If attention is not given to encouraging and developing academic staff that are "Willing and able," and to providing training, support, and mentoring to less experienced academic staff ("Willing, but underexposed"), the ini-

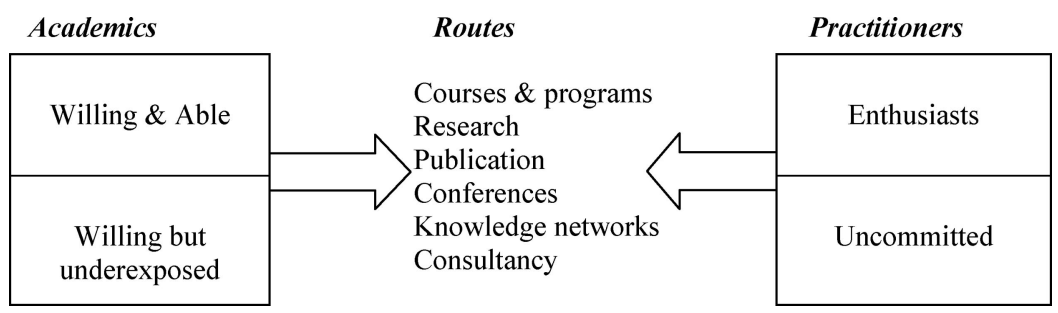

FIGURE 3

Engaging Appropriate People by Multiple Routes 
tiatives will fall flat. Similarly, better understanding of different practitioner attitude segments is essential, in order to focus efforts on those practitioners who are potentially receptive.

The map of routes to engagement (see Fig. 1) could also provide a framework for individual academics planning how to undertake and disseminate their own research. This is a potentially important finding, in so far as it relates to the debate about the functionality of existing academic assessment systems. The focus on academic publication, as the single metric of performance (Adler \& Horzing, 2009; Seggie \& Griffith, 2009), is further exposed as an inadequate way of encouraging and rewarding scholarship in a field such as management where the theory-practice link is so much a part of what makes it distinctive (Tranfield \& Starkey, 1998).

As a source of knowledge for practitioners, academics do bring potential benefits. First, academics are not usually using their knowledge as a means to sell other products or services. This academic objectivity is potentially valuable to practitioners seeking advice that is unencumbered by vested interest. Second, the academic perspective comes from outside the "rough and tumble" of dayto-day business concerns and can insert a healthy skepticism into any analysis, going beyond the latest fad or fashion. Third, the management academic has skills in teaching and learning that can contribute to creating behavior change. Fourth, the academic often has access to his or her own networks and colleagues, providing a wider source of expertise, drawing from areas such as the social sciences, humanities, and liberal arts (Starkey \& Tempest, 2008).

We would argue that, too often, these benefits have not been communicated to the vast majority of practitioners, and we are left with unhelpful stereotypes. One stereotype is of the ivory tower academic, out of touch with practice. Another is of the professor as an all-knowing guru. This latter view can be seen as an uncomfortable conspiracy between practitioners, who are looking for expert help in solving difficult problems, and academics, who want to boost their credibility, and perhaps earnings, in the consultancy arena. A more realistic and mature relationship of equals is required, one based on a recognition that many questions in business and management are complex and deep. Practitioners will not always get the easy answers that they would like, but working with business and management academics can be very fruitful in deepening understanding and facilitating change.

\section{FURTHER RESEARCH DIRECTIONS}

A next step on from our exploratory research would be to conduct a more comprehensive investigation into attitude groups; among both academics and practicing managers. Our findings are based on the perceptions of those, on both sides, who are currently involved in some form of engagement. A fuller investigation could provide evidence from wider sample populations of academics and practitioners. For example, do academic "Theoreticians" see themselves as such? Are most practitioners negative about academia (members of the "Cynical" attitude group) or just waiting to be convinced (members of the "Uncommitted" attitude group)? It would extend our understanding to quantify the size of the different attitude groups and understand their relationships with demographic factors, such as age, experience, and gender. Within the academic community, we would speculate the existence of links between career factors, such as previous employment outside of academia and attitude, but this needs to be empirically tested. On the practitioner side, we would expect there to be a link between education experience (such as having taken an MBA), and attitude toward links with academia. Furthermore, other factors, such as size of the practitioner's organization or type of business sector, might be expected to have an impact on propensity for engagement and on capacity to engage. International comparisons may also be particularly informative in identifying factors that promote or discourage engagement across cultures.

Further work is needed to test the relationship between the use of different routes to engagement and the attitude groups on both sides. We would hypothesize a positive relationship between a positive attitude to engagement and the use of multiple routes, and a negative relationship between a negative attitude to engagement and the use of multiple routes. Furthermore, the knowledge network route would seem to be worthy of specific research because of its strong association with many of the cases of effective engagement that we found in our research. Of particular interest would be the relationship between academic-practitioner networks and wider knowledge networks (Van Wijk et al., 2008). This would provide interesting perspectives that would contribute to extending our understanding of interorganizational knowledge transfer and exchange, in general, as well as in the specific area of academic-practitioner engagement. 


\section{APPENDIX \\ Details of Interviewees}

Academics Role and experience

Acmarl

Acmar2

Acmar3

Acmor4

Acmar5

Acmar6

Acmar7

Acacc8

Acacc9

Acaccl0

Acaccll

Acorgl2

Acorgl3

Acorgl4

Acorgl5

Acorgl6

Acorgl7

Acstratl8

Acstrat19

Professor; company director; runs academicpractitioner network

MBA director; trustee of professional body

Visiting professor; chief executive of an academic-practitioner forum

Professor; runs an academic-practitioner network

Program director; academic consultant

Professor; extensive research and consultancy experience

Senior lecturer

Associate dean at a business school

Lecturer at a business school

Lecturer and journal editor

Director of Admissions at a business school

Academic with extensive consultancy experience

Academic with extensive consultancy experience

Professor with extensive consultancy experience

Academic with business development role for a business school

Academic with extensive consultancy experience

Professor with extensive consultancy experience

Dean of highly rated international management college

Professor and Head of Center for Regional Competitiveness [research and consultancy]

Acstrat20 Senior lecturer with international experience

Practitioners Role and experience

Prmarl

Executive within international company; completed MBA around 15 years ago; coauthor of a number of business articles and books

Prmar2

Executive with varied experience of working with academics in various capacities

Prmar3

Prmar4

Prmar5

Senior copywriter in direct marketing agency

Executive within major insurance company

Executive with international company with experience of taking part in company sponsored university executive course

Prmar6 Executive within the food industry who has recently completed a part-time master's degree in a marketing-related area

Prmar7 Executive with extensive experience of working in direct marketing across a number of sectors

Pracc8 Audit partner for international accountancy practice

Pracc9 Technical director of a national accountancy practice

Pracclo Business services partner at a national accountancy practice

Praccll Corporate finance partner at a national accountancy practice

Pracc12 Finance director for major building firm

Praccl3 Finance director for international company

Prorgl4 Experienced manager in public sector (Customs and Excise)
APPENDIX

Continued

\begin{tabular}{|c|c|}
\hline Practitioners & Role and experience \\
\hline Prorgl5 & $\begin{array}{l}\text { Experienced manager in public sector } \\
\text { (Defense) }\end{array}$ \\
\hline Prorgl6 & $\begin{array}{l}\text { Senior manager with extensive experience } \\
\text { in IT industry }\end{array}$ \\
\hline Prorgl7 & Experienced manager in public sector (Health) \\
\hline Prorgl8 & Experienced manager in finance sector \\
\hline Prorg19 & Public sector manager (Local Government) \\
\hline Prstrat20 & $\begin{array}{l}\text { Strategic planning manager of major } \\
\text { aerospace company }\end{array}$ \\
\hline Prstrat21 & Chief executive of engineering company \\
\hline Prstrat22 & Strategy director of NHS Primary Care Trust \\
\hline Prstrat23 & $\begin{array}{l}\text { International director of engineering } \\
\text { company }\end{array}$ \\
\hline Prstrat24 & Strategy director public service organization \\
\hline Prstrat25 & Partner in regional law practice \\
\hline Prstrat26 & $\begin{array}{l}\text { Managing director of SME construction } \\
\text { company }\end{array}$ \\
\hline Prstrat27 & Director of a family business \\
\hline Prstrat28 & Director of a family business \\
\hline
\end{tabular}

\begin{tabular}{|c|c|}
\hline $\begin{array}{l}\text { Consultants/ } \\
\text { experts }\end{array}$ & Role and experience \\
\hline Conmarl & $\begin{array}{l}\text { Partner in consultancy; recently completed a } \\
\text { DBA }\end{array}$ \\
\hline Conmar2 & $\begin{array}{l}\text { Partner in training consultancy; previously } \\
\text { executive in international blue chip } \\
\text { company; author of a number of business } \\
\text { books }\end{array}$ \\
\hline Conmar3 & $\begin{array}{l}\text { Freelance consultant; recently completed an } \\
\text { MBA; previously executive in a number of } \\
\text { companies }\end{array}$ \\
\hline Conmar4 & $\begin{array}{l}\text { Founder and director of professional body } \\
\text { within the marketing field; leading } \\
\text { authority in his field; published author }\end{array}$ \\
\hline Conmar5 & $\begin{array}{l}\text { Partner in training consultancy; previously } \\
\text { executive in large blue chip company; } \\
\text { completed MBA } 5 \text { years ago }\end{array}$ \\
\hline Conmar6 & $\begin{array}{l}\text { Head of independent research group; } \\
\text { business author }\end{array}$ \\
\hline Conmar7 & $\begin{array}{l}\text { Leading journalist specializing in the } \\
\text { marketing field with regular column in the } \\
\text { marketing press }\end{array}$ \\
\hline Conacc8 & $\begin{array}{l}\text { Technical manager in financial reporting for } \\
\text { a professional body }\end{array}$ \\
\hline Conacc 9 & $\begin{array}{l}\text { Deputy editor of major professional } \\
\text { publication }\end{array}$ \\
\hline Conacclo & $\begin{array}{l}\text { Part of research committee of international } \\
\text { accountancy body }\end{array}$ \\
\hline Conaccll & Head of education for professional body \\
\hline Conorgl2 & $\begin{array}{l}\text { Ex-director of university faculty, now a } \\
\text { private consultant }\end{array}$ \\
\hline Conorgl3 & $\begin{array}{l}\text { Former academic now a commercial } \\
\text { consultant }\end{array}$ \\
\hline Conorgl4 & $\begin{array}{l}\text { Experienced commercial consultant and } \\
\text { visiting lecturer }\end{array}$ \\
\hline Conorgl5 & $\begin{array}{l}\text { Experienced public sector manager then } \\
\text { commercial consultant and visiting } \\
\text { lecturer }\end{array}$ \\
\hline Constrat 16 & Experienced commercial consultant \\
\hline Constratl7 & Head of employers representative body \\
\hline Constratl8 & Experienced commercial consultant \\
\hline Constrat19 & $\begin{array}{l}\text { Senior official of national body representing } \\
\text { regional employers' bodies }\end{array}$ \\
\hline Constrat20 & $\begin{array}{l}\text { Senior official of body representing an } \\
\text { employers' association }\end{array}$ \\
\hline
\end{tabular}




\section{REFERENCES}

Adler, N. J., \& Harzing, A. 2009. When knowledge wins: Transcending the sense and nonsense of academic rankings. Academy of Management Learning \& Education, 8: 72-95.

Alteroff, C., \& Knights, D. 2009. Making and mending your nets: Managing relevance, participation and uncertainty in academic-practitioner knowledge networks. British Journal of Management, 20: 125-142.

Amabile, T. M., Patterson, C., Mueller, J., Wojcik, T., Odomirok, P. W., Marsh, M., \& Kramor, S. J. 2001. Academic practitioner collaboration in management research: A case of crossprofession collaboration. Academy of Management Journal, 44(2): 418-431.

Anderson, N., Herriot, P., \& Hodgkinson, G. P., 2001. The practitioner-researcher divide in industrial, work and organizational (IWO) psychology: Where are we now and where do we go from here? Journal of Occupational and Organizational Psychology, 74: 391-411.

Bailey, J., \& Ford, C. 1996. Management as science versus management as practice in postgraduate business education. Business Strategy Review, 7(4): 7-12.

Baldridge, D. C., Floyd, S. W., \& Markoczy, L. 2004. Are managers from Mars and academicians from Venus? Toward an understanding of the relationship between academic quality and practical relevance. Strategic Management Journal, 25: 1063-1074.

Beer, M. 2001. Why management research findings are unimplementable: An action science perspective. Reflections, 2(3): $58-65$.

Bell, M. 2009. Introduction: Special Section, Doing Work That Matters. Academy of Management Learning \& Education, 8: 96-98.

Bennis, W. G., \& O'Toole, J. T. 2005. How business schools lost their way. Harvard Business Review, May: 96-104.

Birkinshaw, J. 2001. Why is knowledge management so difficult? Business Strategy Review, 12(1): 11-18.

Blackler, F. 1995. Knowledge, knowledge work and organizations: An overview and interpretation. Organization Studies, 16(6): 1021-1046.

Brown, J. S., \& Duguid, P. 1998. Organizing knowledge. California Management Review, 40(3): 90-111.

Cook, S. D. N., \& Brown, J. S. 1999. Bridging epistemologies: The generative dance between organizational knowledge and organizational knowing. Organization Science, 10(4): 381400.

Crowther, D., \& Carter, C. 2002. Legitimating irrelevance: Management education in higher education institutions. The International Journal of Educational Management, 16(6): $268-278$.

Cyert, R. M., \& Goodman, P. S. 1997. Creating effective universityindustry alliances: An organizational learning perspective. Organizational Dynamics, Spring: 45-57.

Denzin, N. K., \& Lincoln, Y. S. 2002. Handbook of qualitative research, 2nd ed. CA: Sage.

Easterby-Smith, M., Lyles, M. A., \& Tsang, E. W. K. 2008. Interorganizational knowledge transfer: Current themes future prospects. Journal of Management Studies, 45: 677-690.

Gerson, K., \& Horowitz, R. 2002. Observation and interviewing: Options and choices in qualitative research. In T. May,
(Ed.), Qualitative Research in Action: 144-160. London: Sage.

Ghoshal, S. 2005. Bad management theories are destroying good management practice. Academy of Management Learning \& Education, 4: 75-91.

Gibbons, M., Limoges, C., Nowotny, H., Schwartzman, S., Scott, P., \& Trow, M. 1994. The new production of knowledge. The dynamics of science and research in contemporary societies. London: Sage.

Godfrey, P. C., \& Hill, C. W. L. 1995. The problem of unobservables in strategic management research. Strategic Management Journal, 16: 519-533.

Grey, C. 2001. Re-imagining relevance: A response to Starkey and Madan. British Journal of Management, 12: 27-32.

Guba, E. G., \& Lincoln, Y. S. 1994. Competing paradigms in qualitative research. In N. K. Denzin, \& Y. S. Lincoln, (Eds.), Handbook of Qualitative Research. CA: Sage.

Guest, D. E. 2007. Don't shoot the messenger: A wake up call for academics. Academy of Management Journal, 50(5): 10201026.

Gummeson, E. 2002. Practical value of adequate marketing management theory. European Journal of Marketing, 36(3): 325-349.

Guzman, G. A. C., \& Wilson, J. 2005. The 'soft' dimension of organizational knowledge transfer. Journal of Knowledge Management, 9(2): 59-74.

Hansen, M. T. 1999. The search-transfer problem: The role of weak ties in sharing knowledge across organization subunits. Administrative Science Quarterly, 44(1): 57-81.

Hatchuel, A. 2001. The two pillars of new management research. British Journal of Management, 12(Special Issue): 33-39.

Healy, M., \& Perry, C. 2000. Comprehensive criteria to judge validity and reliability of qualitative research within the realism paradigm. Qualitative Market Research: An International Journal, 3(3): 118-126.

Huff, A. S. 2000. 1999. Presidential address: Changes in organizational knowledge production. Academy of Management Review, 25(2): 288-293.

Huff, A. S., \& Huff, J. O. 2001. Re-focusing the business school agenda. British Journal of Management, 12(Special Issue): S49-S54.

Huff A. S., Tranfield, D., \& Van Aken, J. E. 2006. Management as a design science mindful of art and surprise. Journal of Management Inquiry, 15(4): 413-424.

Kaplan, R. S. 1989. Connecting the research-teaching-practice triangle. Accounting Horizons, 3(1): 129-132.

Kogut, B., \& Zander, U. 1992. Knowledge of the firm, combinative capabilities, and the replication of technology. Organization Science, 3: 383-397.

Landry, R., Amara, N., \& Lamari, M. 2001. Utilization of social science research knowledge in Canada. Research Policy, 30: 333-349.

Lang, J. C. 2001. Managerial concerns in knowledge management. Journal of Knowledge Management, 5(1): 43-57.

Lave, J. 1993. The practice of learning. In S. Chaiklin, \& J. Lave, (Eds.), Understanding practice: Perspectives on activity and context: 3-32. Cambridge: Cambridge University Press.

Learmonth, M. 2008. Speaking out: Evidence-based manage- 
ment: A backlash against pluralism in organizational studies? Organization, 15(2): 283-291.

Leavitt, H. J. 1989. Educating our MBAs: On teaching what we haven't taught. California Management Review, Spring: $38-50$.

Lincoln, Y., \& Guba, E. 1985. Naturalistic inquiry. CA: Sage.

Lyles, M. A., \& Salk, J. E. 1996. Knowledge acquisition from foreign parents in international joint ventures: An empirical examination in the Hungarian context. Journal of International Business Studies, 27: 877-903.

Magee, B. 1985. Popper. London: Fontana.

Marshall, C., \& Rossman, G. 1989. Designing qualitative research. London: Sage.

Mason, J. 1996. Qualitative researching. London: Sage.

Miles, M. B., \& Huberman, A. M. 1994. Qualitative data analysis, 2nd ed. CA: Sage.

Mintzberg, H. 1996. Musings on management. Harvard Business Review, 74: 61-67.

Mintzberg, H. 2004. Managers not MBAs. London: Pearson Education.

Mintzberg, H., \& Gosling, J. 2002. Managing beyond borders. Academy of Management Learning \& Education, 1: 64-76.

Mohrman, S. A., Gibson, C. B., \& Mohrman, A. M. 2001. Doing research that is useful to practice: A model and empirical exploration. Academy of Management Journal, 44(2): 357375 .

Nonaka, I. 1994. A dynamic theory of knowledge creation. Organization Science, 5(1): 14-37.

Nowotny, H., Scott, P., \& Gibbons, M. 2001. Re-thinking science: Knowledge and the public in an age of uncertainty. Oxford: Blackwell.

Patton, M. 1987. How to use qualitative methods in evaluation. Newbury Park: Sage.

Pettigrew, A. M. 1997. The double hurdles for management research. In T. Clarke (Ed.), Advancement in organizational behaviour: Essays in honour of J. S. Pugh: 277-296. London: Dartmouth Press.

Pfeffer, J., \& Fong, C. T. 2002. The end of business schools? Less success than meets the eye. Academy of Management Learning \& Education, 1: 78-95.

Porter, L. W., \& McKibbin, L. E. 1988. Management education and development: Drift or thrust into the 21st century. New York: McGraw-Hill.

Rynes, S. L. 2007. Editor's afterword. Let's create a tipping point: What academics and practitioners can do, alone and together. Academy of Management Journal, 50(5): 1046-1054.

Sammarra, A., \& Biggiero, L. 2008. Heterogeneity and specificity of inter-firm knowledge flows in innovation networks. Journal of Management Studies, 45: 785-814.

Seggie, S. H., \& Griffith, D. A. 2009. What does it take to get promoted in marketing academia? Understanding excep- tional publication productivity in the leading marketing journals. Journal of Marketing, 73(1): 122-132.

Shapiro, D. L., Kirkman, B. L., \& Courtney, H. G. 2007. Perceived causes and solutions of the translation problem in management research. Academy of Management Journal, 50(2): 249-266.

Shrivastava, P., \& Mitroff, I. I. 1984. Enhancing organizational research utilization: The role of decision makers' assumptions. Academy of Management Review, 19(1): 18-26.

Starkey, K. 2001. In defence of modes one, two and three: A response. British Journal of Management, 12(Special Issue): 77-80.

Starkey, K., \& Madan, P. 2001. Bridging the relevance gap: Aligning stakeholders in the future of management research. British Journal of Management, 12(Special Issue): 3-26.

Starkey, K., \& Tempest, S. 2008. A clear sense of purpose? The evolving role of the business school. Journal of Management Development, 27: 379-390.

Tranfield, D., \& Starkey, K. 1998. The nature, social organization and promotion of management research: Towards policy. British Journal of Management, 9: 341-353.

Tranfield, D., Denyer, D., \& Smart, P. 2003. Towards a methodology for developing evidence-informed management knowledge by means of systematic review. British Journal of Management, 14: 207-222.

Tsoukas, H. 1989. The validity of idiographic research explanations. Academy of Management Review, 14(4): 551-561.

Tsoukas, H. 2005. Complex knowledge: Studies in organizational epistemology. Oxford: Oxford University Press.

Van Aken, J. E. 2004. Management research based on the paradigm of the design sciences: The quest for field tested and grounded technological rules. Journal of Management Studies. 41(2): 219-246.

Van Aken, J. E. 2005. Management research as design science: Articulating the research products of mode 2 knowledge production in management. British Journal of Management, 16: 19-36.

Van de Ven, A. H. 2007. Engaged Scholarship: A Guide for Organizational and Social Research. Oxford: Oxford University Press.

Van de Ven, A. H., \& Johnson, P. E. 2006. Knowledge for theory and practice. Academy of Management Review, 31(4): 802821.

Van Wijk, R., Jansen, J. J. P., \& Lyles, M. A. 2008. Inter- and intra-organizational knowledge transfer: A meta-analytic review and assessment of its antecedents and consequences. Journal of Management Studies, 45: 830-852.

Weick, K. 2001. Gapping the relevance bridge: Fashions meet fundamentals in management research. British Journal of Management, 12(Special Issue): 71-75.

Zahra, S. A., Ireland, R. D., \& Hitt, M. A. 2000. International expansion by new venture firms: International diversity, mode of market entry, technological learning and performance. Academy of Management Journal, 43: 925-950. 
Tim Hughes (PhD, University of the West of England) is a reader in applied marketing at Bristol Business School, University of the West of England. His research interests include academic-practitioner engagement in management and also service-dominant logic, in relation to considering the impact of self-service technology on service provision.

David Bence (PhD, University of the West of England) is a chartered accountant (ICAEW) and lecturer in corporate finance, financial strategy, and financial statement analysis at Bristol Business School, University of the West of England. His main research interests are business valuation, financial reporting theory, and knowledge exchange.

Louise Grisoni ( $\mathrm{PhD}$, University of the West of England) is a principal lecturer of organization studies at Bristol Business School, University of the West of England. Current research interests include aesthetics and arts-based inquiry, organizational learning and development, leadership and public-sector management.

Nicholas O’Regan (PhD, Middlesex University) is a professor of strategy/enterprise and innovation at Bristol Business School, University of the West of England. His research interests include the organizational culture, leadership and the strategic planning processes of smalland medium-sized organizations.

David Wornham (MBA, London Business School) is the director of business development at Bristol Business School, University of the West of England. His research interests cover knowledge exchange between universities and the commercial sector, consulting practice, and the relation between strategy and corporate social responsibility. 
Copyright of Academy of Management Learning \& Education is the property of Academy of Management and its content may not be copied or emailed to multiple sites or posted to a listserv without the copyright holder's express written permission. However, users may print, download, or email articles for individual use. 